This is the accepted manuscript of the article, which has been published in Stegmann McCallion M. \& Brianson A. (eds) Nordic States and European Integration : Awkward Partners in the North? Cham: Palgrave Macmillan.

Palgrave Studies in European Union Politics. ISBN: 978-3-319-57561-2. https://doi.org/10.1007/978-3-319-57562-9_3

\title{
Re-assessing Finland's integration policy: the end of domestic consensus?
}

\author{
Hanna Ojanen and Tapio Raunio ${ }^{1}$ \\ University of Tampere
}

\begin{abstract}
Pragmatism and adaptability are the qualities most often associated with Finland's European policy. In the European context, they manifest themselves in the political elite's view that national interests can be best pursued through active and constructive participation in EU decision-making. Finnish integration policy has thus stood in quite striking a contrast to the EU policies of Denmark and Sweden, both of which have been far less supportive of further integration. Finland has pursued what has often been labelled as a model pupil strategy, a policy which has made it characteristically pro-mainstream and anti-awkward. Re-assessing this traditional image of Finland, we argue that beneath the veil of domestic consensus were strong disagreements over Europe, both regarding policy and procedure, or how EU was approached domestically. The post-2010 situation has brought the disagreements into light. The euro crisis has shaken the foundations of this prointegrationist approach, bringing to the surface the internal divisions that exist among both political parties and the public over Europe and even affecting EU level bargaining. Moreover, the war in Ukraine and Russia's actions in the neighbourhood have led to questions about Finland's foreign and security policy, especially about the extent to which Finnish external relations and relations with Russia are tied to European level decisions. Party-political contestation over the EU sets stronger constraints on government behaviour in Brussels and lessening political consensus paves way to more potential for changes and unexpected behaviour, thus a certain awkwardness. At the same time, we see continuity: even if more critical than before, Finland might still be firmly in the
\end{abstract}

\footnotetext{
${ }^{1}$ The authors would like to thank Ilmari Uljas for apt research assistance.
} 
mainstream, because the mainstream itself has changed. The gains and losses caused by integration are now more thoroughly calculated, and the commitment of member states to the goals of the Union has arguably weakened. For Finland, the euro crisis and the deteriorated security situation have underlined the importance of the European framework for advancing national interests.

\section{Introduction}

Finland's integration policy has traditionally been characterized as flexible and constructive. Successive governments have constantly underscored the importance of taking part in decisions concerning Finland. According to the political elite, national interests can be best pursued through active and constructive participation in European Union (EU) decision-making. Underlying this stance is a conviction that strong and efficient European institutions and common rules can best protect the rights and interests of smaller member states, as intergovernmental processes tend to favour the larger member states. Pragmatism and adaptability, behavioural traits influenced by Cold War experiences, are the leading qualities of Finnish EU policy,. This also means a pragmatic attitude towards the definition of 'national interest': what is seen to be in the national interests may well change in the process of integration.

Finnish integration policy stands thus in quite striking contrast to the EU policies of Denmark and Sweden (and of course Norway and Iceland), both of which have been far less supportive of further integration. Interestingly, such a divergence was not foreseen. Some had predicted, especially after the divisive EU membership referendum of October 1994, that Finland would follow the path of Denmark with its cautious integration policy. Others expected an intra-Nordic division to go between, on the one hand, Denmark as a footnote country, and, on the other, Sweden and Finland as adaptive countries and even potential 'model pupils' (Mouritzen 1993). In the end, it was Finland that appeared to jump in from the cold, from a neutral outlier to a country aiming at the very 'core' 
of the Union. Sweden did not follow. A good illustration of the difference in attitude was the Economic and Monetary Union (EMU). Finland is the only Nordic country that belongs to the euro zone, with the single currency adopted as a done deal and without much political contestation. Sweden interpreted the same situation differently taking the political freedom to postpone its entry to the EMU, staying out of euro. (Ojanen 2004.) ${ }^{2}$

Another illustration of adaptation was the reformulation of neutrality. Both Finland and Sweden reformulated their neutrality policies as military non-alignment and declared it as compatible with EU membership and the Common Foreign and Security Policy (CFSP). Both also strived to show activism in this field and committed considerable resources to it, actually bringing integration forward. The change was, however, particularly striking for Finland, as it had earlier on approached security cooperation with great caution, avoiding binding commitments and political cooperation. Now, it stressed solidary and the security-enhancing impact of membership. (Ojanen 2000, Ojanen et al. 2000; Raunio \& Tiilikainen 2003; Tiilikainen 2006; Raunio 2015.)

In terms of awkwardness, Finland would seem to belong to a category of its own: it is a country that has from the start of its membership on purpose aimed at being non-awkward. In other words, it has been careful in not causing trouble or being difficult to deal with; it has stayed firmly in the mainstream being fully committed to the goals of the Union. Moreover, it has sought to use whatever own influence it might have in a way that advances the interests of the whole Union, and been careful in not stressing national interests too much.

${ }^{2}$ In Finland the Centre Party demanded a referendum on the issue, however. In Sweden, a referendum on the euro was organised in 2003. 
Re-assessing this traditional image of Finland as an adaptive and integrationist EU country, we argue that beneath the veil of domestic consensus were strong disagreements over Europe. This applied to both national integration policy and to procedure or how EU affairs were handled in Finland. In order to put our argument into contextual perspective, we first explain the reasons why Finland joined the EU and the importance attached to consensual mode of decision-making before providing evidence of the changes. The euro crisis has certainly shaken the foundations of this prointegrationist approach, bringing to the surface the internal divisions that exist among both political parties and the public over Europe. In particular, the crisis ushered in an era of unprecedented domestic politicization of Europe, with this contestation over euro zone bailout measures and the further development of integration affecting the work of national political institutions and cabinet formation and even EU level decision-making. Moreover, the war in Ukraine and the deteriorating security situation in the neighbourhood have led to questions about Finland's foreign policy, especially about the extent to which Finnish external relations and relations with Russia are tied to European level decisions The domestic debates have clearly revealed the tensions between those favouring a more supranational EU and those more in line with an intergovernmental vision of Europe.

\section{Joining the 'West' for economic, security and cultural reasons}

When the Cold War had ended and the Soviet Union collapsed, Finland wasted no time in seizing the opportunity to become fully engaged in European integration. While joining the European Community (EC) was not on the political agenda during the Cold War, Finnish industry, especially the influential wood processing sector, had expressed its preferences by exporting heavily to Western Europe (Väyrynen 1993). Finland took part in the negotiations on the formation of the European Economic Area (EEA) in 1990 and joined it in 1994 (Ojanen 2004). Application for EC membership followed suit in March 1992. Once the membership application was made, a broad 
majority of the national decision-making elite - government, parliamentary majority, trade unions and employers' organisations, main political parties, the president, most of the media - emerged in favour of EU membership. Finland joined the EU from the beginning of 1995, following a membership referendum held in October 1994 in which $57 \%$ voted in favour of entering the Union (Pesonen 1994; Arter 1995; Jenssen et al. 1998). ${ }^{3}$

The broad support for membership shown by the political elites before the referendum is explained by both economic interests and security considerations. Economic factors were strongly emphasized in the membership debates. Finland is heavily dependent on trade, and the demise of the communist bloc increased trade dependence on the EU countries. Apart from trade concerns, the heavy recession of the early 1990s, including the instability in monetary policy and the devaluation of markka, further convinced the industry and the trade unions about the importance of joining the Union. The only significant interest group campaigning against membership was The Central Union of Agricultural Producers and Forest Owners, a position explained by the anticipated negative impact of the Common Agricultural Policy (CAP) on the farming sector.

In addition to any lessons learned from history and the Cold War, the rather uncertain political situation in Russia brought security concerns to the fore. While security policy considerations were initially downplayed during the referendum campaign, there is no doubt that the security dimension was a key factor behind the decision of both the elite and the voters to support EU membership. Indeed, the importance accorded to security policy is arguably what distinguishes the Finnish case

\footnotetext{
${ }^{3}$ Only two minor Eduskunta parties were against membership: the Christian Democrats (then as the Christian League) and the Rural Party (the predecessor of the Finns Party). The Left Alliance and the Green League were so divided over the issue that they decided not to adopt positions either for or against membership.
} 
from the other Nordic countries. It was because of security considerations that Finland could not have joined the EU any earlier. Once an EU member, Finland gave great importance to the new provisions of the Maastricht Treaty on CFSP and the security-enhancing impact of membership. The quest towards the very 'core' of the Union also signalled a wish to be associated with the 'right' reference group: not with the reluctant Nordic neighbours, but rather, the pro-integrationist Benelux countries, or with Germany. (Ojanen 2004: 161-162.)

Moreover, there was a broader cultural argument about (re-)joining the West. While the pro-EU camp argued that by joining the Union Finland would merely be maintaining or consolidating its place among west European countries, there is little doubt that especially among foreign observers the 'western' identity of Finland had been far less clear. Indeed, the significance of EU membership for Finland should not be underestimated, for it clearly constituted a key element in the 'process of wholesale re-identification on the international stage' (Arter 2000: 691).

\section{The importance of domestic consensus}

The Finnish political system is often characterized as consensual. Decision-making is pragmatic and based on broad consultation with key interest groups, not least with the main corporatist actors, the trade unions and the employers' organisations. The shape of the Finnish party system, with no party as a rule winning more than $25 \%$ of the votes in Eduskunta (the unicameral national legislature) parliamentary elections, also facilitates consensual governance and ideological convergence between all the parties aspiring to enter the government. Cabinets are typically majority coalitions that bring together parties from the left and the right. The dividing line between government and opposition has become more clear as a result of recent constitutional reforms, but the pragmatic and consensual style of politics still largely prevails, particularly in EU and foreign policy matters. (E.g., Arter 2006; 2009; Karvonen 2014; Ruostetsaari 2015; Karvonen et al. 2016; Raunio 2016a.) 
From the start of EU membership until the outbreak of the euro crisis in spring 2010 Finland used to have a relatively broad consensus about Europe among its political parties. The divisive nature of the EU membership referendum held in 1994, however, indicated that the commitment to integration which prevailed among the political parties was not shared to the same extent by the electorate. There has thus been a notable lack of congruence between the citizens and the political parties, with most parties considerably more supportive of the EU than their supporters (Mattila \& Raunio 2005; 2012). Hence it is not surprising that overall the Finnish parties kept a fairly low profile in integration matters, with also the rules of the national EU coordination system - based on building broad domestic elite consensus, including often between the government and opposition parties, which can arguably be translated into additional influence in EU level bargaining contributing to the depoliticization of European issues (Raunio 2005; Hyvärinen \& Raunio 2014). ${ }^{4}$

Consensus on foreign and security policy has traditionally been even stronger. Finland is a small country and in many senses dependent on stable and good international relations. Underlining the Finnish appreciation of consensus is the belief that such a small country is vulnerable if it shows internal differences of views, or cleavages concerning its foreign and security policy. These cleavages could be used by outsiders to damage its negotiation position, and they might also be encouraged from the outside, thus destabilising Finnish politics. Therefore, the tradition has been not to debate foreign and security policy very much in the open. Efforts at actually stopping or restraining the debate with the argument that "it is not the right time for discussion" have not been

\footnotetext{
${ }^{4}$ It also appears that until the current euro crisis the EU did not become as salient an issue as in the other Nordic countries, leaving thus parties more freedom to execute their preferred strategies. In contrast to the other Nordic countries, there were in Finland fewer issues around which to wage anti-EU campaigns (like the euro in Sweden and Denmark or fisheries policy in Norway).
} 
rare, particularly when it comes to the Government Security and Defence Policy Reports or NATO membership. An example would be the plea of President Sauli Niinistö to party leaders that NATO would not be taken up in the debates before the 2015 Eduskunta elections. ${ }^{5}$

The importance of consensus has stretched to cover also CFSP and the understanding that EU membership is important for Finnish security, even the view that the stronger the EU is in this field, the better it is for Finland. Together with the parliamentarisation of foreign policy that resulted from the constitutional change in 2000, more possibilities for genuine debate have been created. Yet, the recent problems in Russia and the deteriorating security situation in the region is a factor that may make this growing pluralism again a potential security problem in itself, leading to highlighting the need for consensus even more than before.

\section{'Special relationship' with Russia and the new European foreign and security policy}

For centuries, Finland has been a 'borderland' in between east and west, as a part of Sweden, as part of Russia, and then from 1917 on, as an independent state trying to find its position between east and west (Tiilikainen 1998; Alapuro 2004). During the Cold War Finland had close economic and political ties with the Soviet Union, consolidated in the Treaty of Friendship, Cooperation and Mutual Assistance (FCMA) signed in 1948. The FCMA treaty constituted limitations to Finnish armed forces, and prohibited military cooperation with any country hostile to the Soviet Union. The Cold War entailed a delicate balancing act, with priority to good relations with the Soviet Union

\footnotetext{
${ }^{5}$ The Finnish broadcasting company YLE in its news item on this meeting reported the president to have concluded that the parties shared a common view implying that none of them was proposing membership application but neither were they ruling such possibility out (http://yle.fi/uutiset/presidentti_niinisto_tapasi_puoluejohtajat_natohakemus_ei_ole_ajankohtainen/7700687).
} 
reconciled with democratic political institutions at home and integration into western markets. While the direct interference of the Soviet leadership in Finnish politics has often been exaggerated, the Finnish political elite nevertheless was always forced to anticipate the reactions from Moscow, and this set firm limits to Finland's cooperation with Western European and Nordic countries.

During the Cold War Finnish foreign policy was very much driven by the policy of neutrality, which culminated in 1975 when Finland hosted the Conference on Security and Cooperation in Europe (CSCE). From the mid-1960s at least until the mid-1980s, this foreign policy line enjoyed virtual unanimous political and public approval. During the long reign of President Urho Kekkonen (1956-1981) foreign policy was personally identified with the president, who was more or less visibly supported by political elites within the Soviet Union. Political debate and contestation on foreign policy were rare during this era of 'compulsory consensus' that placed a premium on maintaining amicable relations with the Soviet Union (Arter 1987).

Concerns about national security influenced voting behaviour in the 1994 membership referendum, but at the same time it was understandable that many commentators in Finland and abroad questioned whether the 'special relationship' with Russia - relationship which also in economic terms had been very important for Finland - would hinder Finland's participation in CFSP. Others in turn argued that even when operating in the EU context, Finland should strive to maintain strong bilateral relations with Moscow. Hence the compatibility between Finnish foreign policy and the CFSP had to be proven for both domestic and European audiences. One important part of this compatibility was the understanding that CFSP did not necessitate altering relations with neighbours, i.e., with Russia, and that defence decisions - should defence policy come to be discussed in the future - would be based on unanimity (Ojanen 2008). 
To the member states, demonstration of good intentions as to the CFSP was in order. Seen from within the EU, Finland belonged to a group of neutral countries. As candidate countries, they were looked at with some suspicion: many member states thought these countries might not be willing to contribute to the new foreign and security policy and the possibility of a common defence policy in formation, but might in fact try to hamper it. Austria, Finland and Sweden did have to sign a special declaration confirming that they would be constructive participants. (Ojanen 1998: 292-293) Of these three countries, Finland quickly adopted a particularly positive rhetoric about the EU's security-enhancing impact. The Government Security and Defence Policy Report of 1995 went as far as to state that Union membership will help Finland to repel any military threats and prevent attempts to exert political pressure. Furthermore, it displayed the idea of a 'model pupil' that by its own loyalty ensures support from the others: "by sharing in these collective efforts, Finland can expect support from other members for its own aspirations and for its position." (Ojanen 2008: 58$60)$.

Together with Sweden, Finland started its membership in a remarkably active way: in the preparation of the Amsterdam Treaty, they proposed adding the Petersberg tasks, or crisis management, to the treaty. Once accomplished, both countries also showed generosity in committing civilian and military capabilities to the EU, and later on, they have actively participated in its various crisis management operations as well as the Battle Groups (Ojanen 2000; 2008). The basic reason for this activism was no doubt to spell the doubts about their credibility as partners in this field. Secondarily, there was the idea that multilateralism might indeed strengthen Finnish security: the new understanding gained ground that Finland might be in a stronger position as an EU member than what it was alone, and this applied also to relations with Russia. 
At the same time, Finland tried to influence the EU's views and policies on Russia. Finland's early membership years were also characterised by activism in engaging the EU in northern affairs. The initiative for a "Northern Dimension" of the EU, presented in 1997, was a way for Finland to ensure that the EU would not lose sight of its northernmost regions in the wake of what looked like an imminent new enlargement to the east. Even more importantly, it was a way for Finland to insert its interests when it came to the relations between the EU and Russia, or to 'customise its Union' in this field (Ojanen 1999). At that point, Finland was the only EU member country with a border with Russia, and Finland soon also found itself in a position where its expertise on Russia was called for, the drafting of the common strategy on Russia in 1999 being one example (Haukkala \& Ojanen 2011). General interest towards Russia in the EU was low, and the Finnish emphases on positive interdependence and inclusion of non-EU partners, Russia but also others, hardly met opposition (Ojanen 2000).

While the early years of membership entailed diverse and significant adaptation to EU foreign policy $^{6}$, they were also characterised by Finland's successful impact on the most critical parts of this policy, the relations with Russia. The overall sense of compatibility between Finnish and EU interest strengthened Finland's belief in integration and multilateralism. A high point of multilateralism may have been achieved in 2000 when the Finnish President Tarja Halonen was asked whether bilateral relations with Russia still mattered, and her answer was: they are the same as the EU has adopted the Finnish policy on Russia (Pursiainen \& Saari 2002: 22).

An important extra-regional security provider is often seen as a major cause for awkward behaviour within a regional constellation. Russia as the most important external security factor for Finland

\footnotetext{
${ }^{6}$ On adaptation and Europeanisation in Finnish foreign policy, see also Jokela (2011) and Palosaari (2011).
} 
could well count as a reason for Finnish behaviour, but not as a reason for awkwardness. The Finnish strongly mainstreamist EU-policy managed to reconcile this external factor with an active and committed European stand. Influencing the EU's policies on Russia (also through the Northern Dimension initiative) was a clear case of exerting constructive influence, as opposed to awkward behaviour or obstructionism.

But the situation was soon to change. A fundamental worry from the beginning had been that Finland could be entangled in the problems between the EU and Russia, should their relations deteriorate. Not even the first years of membership were problem-free, as the first Chechen war in 1994, on the wake of membership, and the second in 1999, during the first Finnish EU presidency, showed. What then started to change the situation was the process of eastern enlargement. The membership of Baltic countries and of Poland meant increasing diversity within the Union and made common policies appear less easy to achieve, but also less reliable and no longer necessarily following Finnish preferences. During its second EU presidency in 2006, Finland did not manage to secure the commencement of negotiations on a new agreement ("post-Partnership and Cooperation Agreement") with Russia. Little by little, this eroded the confidence in EU policies: where they were seen to fail, Finland engaged itself in "damage control" of some kind through more active bilateral relations. (Haukkala \& Ojanen 2011: 157-159.)

The period of 2001-2003 was one where also the development towards a common defence policy started to cause problems for Finland. 'The stronger, the better' no longer necessarily applied. The crisis management side of the CFSP was still fine, and Finland duly inserted the main contents of the 2003 European Security Strategy in its Government Security and Defence Policy Report of 2004. Inserting a common defence clause in what was then called the Constitutional Treaty, however, caused the four ex-neutral members much trouble. They proposed a much watered down 
version of the clause in which the member states "may request aid", leaving out the obligation of aid and assistance altogether (Ojanen 2008: 61). This was not acceptable to the other member states and the final compromise was one in which the mutual defence commitment stays, but the policy of the Union "shall not prejudice the specific character of the security and defence policy of certain Member States" (art 42:2 Lisbon Treaty).

This could be seen as one of the first instances of Finland actually complicating integration in this field, or acting in an awkward way. Common defence was, for Finland, problematic: the duties it could imply outweighed potential gains. Particularly the defence of the Baltic countries against Russia was looming large as a truly problematic scenario. The notion of being in the 'core' started to look problematic when it came to defence. The possibility of an inner core actually forming in defence policy was worrying for Finland as it would not know on which side it would position itself: it was the idea of a possible split within the Union that worried Finland the most. This was also the reason behind the ex-neutral member countries' letter on the planned defence clause, at least from Finland's point of view: it was imperative to avoid a split within the Union.

The Eastern neighbourhood issues were also to show the differences between Finnish and Swedish stances. Finland, from the outset a more integrationist and supranationalist country than Sweden, took first distance from its Nordic EU neighbours. This included the question of eastern enlargement, where Finland favoured the Commission line (enlargement in waves as the candidates meet the membership criteria, in practice Estonia in the first wave) over the Nordic position (supporting the entrance of all Baltic countries together) (Ojanen et al. 2000: 140). Finland was, as a matter of fact, being an awkward Nordic country during its first EU membership years. Sweden's activism in EU neighbourhood policy and in the Eastern Partnership was not matched with similar Finnish interest. Even the 2008 war in Georgia brought out the differences between Sweden and 
Finland. It led many in Finland to observe that the unchanged territorial defence system was actually good to have while the much reworked and slimmed Swedish defence system seemed to left the country more vulnerable.

Later on, increasing Russian assertiveness and rivalry in the neighbourhood, increasing military activity in the Baltic Sea region, air space violations and new hybrid threat scenarios further accentuated this tendency. The internal divisions between EU member states on Russia become more pronounced, as the overall security situation deteriorated, bringing national interest to the foreground.

\section{The euro crisis: politicization of EU affairs}

Overall, considering the quite Eurosceptical public opinion and the divisions inside parties, there was a societal demand or at least potential for more contestation over EU and national integration policy. The domestic politicization of the euro crisis, coinciding with the 2011 Eduskunta election campaign, was thus perhaps not that surprising, but it certainly has changed the nature of national EU discussion and has even affected European level decision-making.

Economic factors played a key role in the decision to join the Union, and, if anything, the euro crisis seems to have further convinced at least the political and economic elites of the values of internal market and monetary stability. As one of the euro zone countries with triple-A rating, Finland has supported tight budgetary discipline, emphasizing that the success of the single currency and European economy depends on the performance of national economies. But while Finnish governments have consistently supported various euro area rescue and coordination measures from bailout payments to Fiscal Compact and the banking union, they have certainly needed to pay closer attention to the mood at home. 
In the run-up to the 2011 Eduskunta elections the problems affecting the euro zone triggered heated debates, and the EU - or more precisely the role of Finland in the bailout measures - became the main topic of the campaign. The decision to rescue Greece from its near bankruptcy showed divisions between and within political parties, and when, just before the elections, first Ireland and then Portugal followed the path of Greece and required bailout measures, the debate only intensified. It is fair to say that no other EU matter has produced similar tensions in Finland since joining the Union. While the opposition parties, as well as a notable share of backbenchers from the governing parties, were clearly angered by the EU's response to the crisis, the debates were also strongly influenced by the upcoming elections. The more Eurosceptic parties (the Finns Party, the Christian Democrats and the Left Alliance) and the main opposition party, the Social Democrats, led the attack on the government. The Social Democrats, perhaps not to be outdone by the Finns Party’s EU critique, adopted a high-profile position against lending money to Greece without bilateral collaterals, and the opposition parties in general voted against the aid measures.

Particularly the Finns Party had an electoral incentive to capitalize on the crisis. It is the only party represented in the Eduskunta that has consistently been opposed to European integration (but without ever demanding Finland's exit from the EU or the euro area) — and also the only party which has systematically used the EU as a central part of its campaigns and political discourse. The Finns Party has forcefully attacked the consensual modes of decision-making and demanded public debates about Europe, calling for an end to 'one truth' politics. Indeed, it was the 'outsider' position which enabled the Finns Party to benefit from these developments. As the party was not part of the consensual arrangements, it could attack the existing status quo and the bailout measures with more legitimacy and credibility than its competitors. 
The election result was nothing short of extraordinary, producing major changes in the national party system and attracting considerable international media attention. The Finns Party ${ }^{7}$ won $19.1 \%$ of the votes, a staggering increase of $15 \%$ on the 2007 elections and the largest ever increase in support achieved by a single party in Eduskunta elections. All the other parties represented in the Eduskunta lost votes. In light of the election campaign, the 'six-pack' National Coalition-led government that entered into office in the summer of 2011 came under serious political pressure to defend national interests in Brussels. Finland demanded as the only country bilateral guarantees on its bailout payments; attempted, on its own, to reject $85 \%$ majority decision-making in the European Stability Mechanism (ESM), demanding unanimity instead; and blocked, together with the Netherlands, the entry of Bulgaria and Romania into the Schengen area. Overall, the success of the Finns Party has clearly pushed the other parties in the direction of more cautious EU discourse. (Raunio 2012b).

The main effects were indeed felt at home, both in the political institutions and in public debate. Turning first to the government, the euro crisis clearly politicized and livened up debates in the ministerial EU committee (officially the Cabinet Committee on European Union Affairs), the main intra-cabinet forum for EU matters (Hyvärinen \& Raunio 2014). More importantly, the euro crisis challenged the institutional norms of parliamentary engagement in EU affairs. Two interconnected features of parliamentary EU scrutiny stand out as particularly relevant: government scrutiny and parliamentary unity. The scrutiny model is primarily designed for controlling the cabinet in EU

\footnotetext{
${ }^{7}$ The party adopted its current English name in August 2011. Until then it had been known as the True Finns. According to the party leader, Timo Soini, the new simpler name is intended to emphasize the fact that the party represents ordinary citizens. Soini also felt that the old name had an extreme right or nationalistic slant to it. The exact translation of the Finnish name of the party, Perussuomalaiset, would be ‘common Finns' or 'ordinary Finns'.
} 
matters, with emphasis on mandating the Brussels-bound ministers in the Grand Committee, the European Affairs Committee (EAC) of the Eduskunta. This emphasis on government scrutiny in EAC has clearly impacted plenary involvement in EU affairs which was until the euro crisis very limited. The objective is to produce unanimous EAC opinions instead of decisions that pit the governing parties against the opposition.

In contrast to previous lack of European debates, between 2010 and 201218 EU debates took place on average per year, with $63 \%$ of them focusing on the euro area (Auel \& Raunio 2014). More interesting are interpellations that have become the standard form of confidence vote. Before 2010 only two were EU-related, with both of them dealing with CAP and its impact on Finland. However, between 2010 and 2015 the opposition tabled six crisis-related interpellations. The first of these was signed by the Left Alliance, while the other five were put forward by the Finns Party. These interpellation debates are well-attended by MPs and the government and attract considerable media coverage. Examining Grand Committee decision-making and outputs, we can see a clear change from 2010-2011 onwards. Voting became more common in the EAC, with the losing opposition minority adding its dissenting opinions to the EAC reports and minutes. Most of the contestation was initiated by the Finns Party, but also the Centre Party entered often its objections to the public parliamentary records. The clear majority of the votes and dissenting opinions were on euro crisis-related issues. Hence the euro crisis ushered in a new era of more contested EAC and parliamentary decision-making in EU affairs. Although problematic for the government (and occasionally by extension for EU decision-making, thus potentially awkward), these developments are good news in terms of democracy and the level of public discussion. The plenary debates about the euro zone were arguably the first time that the government was forced to justify and defend its EU policies in public - and when the opposition attacked the government publicly over its handling of European matters. (Raunio 2016b.) 
The increased contestation has influenced also government formation. In 2011 the Finns Party was close to joining the cabinet, but according to Timo Soini, the long-standing party chair, it was impossible to participate in a government that was committed to further euro zone rescue measures. However, after another strong election result in the 2015 Eduskunta elections, with the Finns Party finishing second in terms of seats and winning $17.7 \%$ of the votes, Soini guided his party to the new right-leaning cabinet that also includes the Centre Party and the National Coalition. With his eyes on post-election coalition formation bargaining, during the campaign Soini had assured voters that the EU and potential bailouts would not be obstacles to his party entering the government. The new Prime Minister, Juha Sipilä, needs also to look over his shoulders given that the Centre has been internally divided over European integration ever since EU membership entered the domestic political agenda in the early 1990s. Two-thirds of Centre supporters voted against membership in the 1994 referendum, and the rank-and-file continue to be sceptical of further integration. The party's parliamentary group also contains diverse views on Europe, and the generally speaking proEU Sipilä may thus be under pressure not to appear too soft when representing Finland in Brussels.

The European section of the government programme is certainly more critical of integration than the programmes of previous cabinets, with Finland seeking 'less, but better and lighter, regulation than at present.' The programme emphasizes strongly that each euro area country is responsible for its own economy, and 'EMU should not be developed through such deepening of economic coordination which would lead to an expansion of joint responsibility'. Sipilä's cabinet is thus 'opposed to increasing Finland's liabilities in handling the euro crisis' and that 'if the European Stability Mechanism must still be used, it should be done only within the framework of the mechanism's current capacity and capital structure'. The programme also states explicitly that the EU 'must act decisively to manage illegal migration flows in the Mediterranean area. Relocation of 
asylum seekers within the EU should be based on the voluntary participation of Member States' ${ }^{8}$ Hence it was not surprising that Finland was in the summer of 2015 among those countries that were most critical of a new Greek bailout package. ${ }^{9}$ In the end the government, including the Finns Party, swallowed the bitter pill and accepted the bailout deal, not least because they realized that under ESM rules Finland could not alone bloc decision-making. And in late September 2015 the government abstained (= voted against) when the Council of the EU decided on relocating 120000 asylum-seekers. ${ }^{10}$

Overall, the euro crisis was a turning point in Finnish EU policy, with party-political conflict and public contestation that clearly constrains the cabinet in EU level bargaining, at least in euro zone decision-making. It may have strengthened similar tendencies in foreign and security policy as well, a field in which the original integration zeal started to show signs of change much earlier, but where stepping out of the consensus tradition is relatively much harder still.

\footnotetext{
${ }^{8}$ Finland, a land of solutions. Strategic Programme of Prime Minister Juha Sipilä’s Government, 29 May 2015. Government Publications 12/2015 (http://valtioneuvosto.fi/en/sipila/governmentprogramme).

${ }^{9}$ The bailout package did not increase Finland's contribution to the stabilization fund. According to many sources Finland was the country most opposed to the deal, with Soini supposedly even threatening to leave the government should Finland agree to new loan arrangements. See for example http://foreignpolicy.com/2015/07/13/the-biggest-roadblock-to-a-greek-deal-could-be-tinyfinland/; http://yle.fi/uutiset/stubb_finland_is_not_alone_in_opposing_greek_bailout/8149043.
}

10 The Czech Republic, Hungary, Romania and Slovakia voted against while Finland abstained. In practice Finland nonetheless voted against the winning coalition as according to the decision rules of the Council what matters is the number of votes in favour of the proposal. 


\section{The crisis in Ukraine: reconsidering the utility of CFSP}

The war in Ukraine has certainly brought to the fore the 'special relationship' with Russia and the question about the proper relation between bilateral or national and EU policies. Economically Russia is a very important trading partner for Finland, and hence the sanctions imposed by the EU and the Russian countermeasures are hitting Finland particularly hard. ${ }^{11}$ Nonetheless, Finland has supported the EU line, with the government and President Sauli Niinistö underlining that there is no other option. The active role of Niinistö during the crisis is also interesting because of the dual leadership system, with Finland's foreign policy co-led by the president and the government (Raunio 2012a). The system is often linked with the distinction between national and European foreign policy. While the government is in charge of the CFSP, the president has a larger role in bilateral relations, especially with non-EU countries.

Would Russia even be a factor that makes Finland turn away from the common EU policy line, or, in other words, turn into a reason for awkward behaviour, as major external security factors often do? Signs of questioning the efficiency and suitability of the sanctions can be found, even though the general support for the EU decisions is officially repeated over and over again. What is interesting, though, is how the debate has changed. Russia plays an active role: seeking for internal splits within the EU, it has tried to influence the image of Finland, give a picture of Finland as a potentially weak link behind the sanctions policy. Also the other EU countries watch Finland quite closely. In the Finnish debate on sanctions, the importance of a united EU front is stressed, but at the same time, the need for good bilateral relations is underlined. Finland has also called for

11 Between 2007 and 2014, Russia was the most important trade partner of Finland. Since 2013, trade with hussia has diminished considerably (http://www.tulli.fi/fi/tiedotteet/ulkomaankauppatilastot/katsaukset/maat/venaja15/index.html?bc=3 70). 
solidarity between the member countries when it comes to the distribution of adverse economic consequences of counter-sanctions, claiming also for compensation from the EU for its losses. At the same time, it has positioned itself among those member countries that have been in favour of a slower schedule for the stepping up of sanctions. The dissenting opinion of Foreign Minister Erkki Tuomioja to the minutes of the Council of the EU ministerial council in September 2014 caused quite some debate. He signalled the readiness of Finland to object to new sanctions even if left alone in this position. ${ }^{12}$ Such a move was quickly interpreted as part of the upcoming election campaign. Later on, Finnish politicians also complained about the EU countries leaving Finland alone with hard choices in the decision concerning the participation of Russians that are on the EU's sanction list in an Organization for Security and Cooperation in Europe (OSCE) parliamentary meeting in Helsinki. ${ }^{13}$ Importantly, the domestic debate has changed, becoming at times quite heated as the politicians accuse each other of either entering a 'grey area' with too many concessions to Russia or of a EU zeal that is dangerous for Finnish interests and, in the end, its security.

Similarly, the programme of the Sipilä cabinet seeks to underline the support for common policies while marking space for bilateralism. On Russia, it says: 'The improvement of relations between Russia and the EU would reinforce the security and economy of Europe as a whole. This cooperation must be based on respect for international law and international commitments', and,

${ }^{12}$ Helsingin Sanomat, 9 September 2014, “Tuomiojan merkintä: Suomi voisi vastustaa Venäjänpakotteita vaikka yksin". .

13 Helsingin Sanomat, 6 July 2015, "Niinistö: Suomi jätettiin yksin Venäjä-ratkaisun kanssa" http://www.hs.fi/politiikka/a1436145697408?ref=hs-art.artikkeli, Hufvudstadsbladet, 7 July 2015 ('Niinistö: Finland satt i en rävsax". http://hbl.fi/nyheter/2015-07-07-762030/niinisto-finland-satt-ien-ravsax). 
'Russia is an important neighbour for Finland. Finland complies with the European Union's common positions on Russia and also maintains diverse bilateral relations.' In addition, Finland will maintain good bilateral relations with other countries.' When it comes to security and defence, the programme states that Finland is a militarily non-allied state which is engaged in a practical partnership with NATO and it maintains the option to seek NATO membership. ${ }^{14}$ Nordic cooperation and in particular bilateral cooperation with Sweden has increased in importance for Finnish security policy. Bilateralism is on the rise also when it comes to relations with the UK and the US.

If at start, Finnish anti-awkward EU policy implied constructive activism in foreign policy, the trend seems to be a downward one. When looking at how Finland has scored in comparison to other member countries in EU foreign policy, it appears that its influence has been in decline for some time already. The Foreign Policy Scorecards from 2010 to $2015^{15}$ show that the overall profile of Finland in CFSP has increasingly diverted from that of Sweden. Finland's activism and influence has been declining, while Sweden has become the most influential member country after the large member states. This also includes relations with Russia, where Sweden has had a consistently active profile. In this period and according to the scorecard methodology, Finland has not been hampering the CFSP, either. As shown in the above, however, in some situations Finland might be inclined to identify itself with those that want rather 'less' than 'more' Europe. Still, even in cases it has actually opposed a decision, such as the Commission's relocation plan for refugees, it has complied with it afterwards.

${ }^{14}$ Finland, a land of solutions. Strategic Programme of Prime Minister Juha Sipilä’s Government, 29 May 2015. Government Publications 12/2015 (http://valtioneuvosto.fi/en/sipila/governmentprogramme).

${ }^{15} \mathrm{http}: / /$ www.ecfr.eu/scorecard/. 


\section{Concluding discussion}

Considering the relatively narrow majority in favour of joining the EU in the referendum held in 1994, Finland would seem to have all the key preconditions for adopting a more intergovernmental approach to European integration. Yet the situation was until the euro crisis very much the opposite, with successive Finnish governments consistently in favour of both deeper policy integration and of increasing the powers of supranational institutions.

In light of the divisions underneath the consensus, the new, more cautious integration policy should not come as a major surprise. The euro crisis revealed the fragile basis of the domestic (elite) consensus over Europe, bringing thus national EU policy arguably more in line with public opinion. The euro crisis and the success of the Finns Party have influenced domestic EU discourse, which is certainly more critical, downplays any moves towards further transfers of power to Brussels, and emphasizes the role of national interests. According to the programme of the Sipilä government 'Finland is an active, pragmatic and result-oriented Member State. The Government will seek, in a constructively critical and cooperative way, to combine the national and joint European interest in Finland's EU policy.' ${ }^{16}$ Overall, there is now more contestation over integration, and importantly much of this conflict takes place in public - in the plenary debates in the Eduskunta and in printed and electronic media. This is certainly a highly positive development when considering that Europe as an issue had remained depoliticized in Finland for such a long time. The more critical domestic climate on Europe has also impacted on EU level bargaining. Increased contestation means more

${ }^{16}$ Finland, a land of solutions. Strategic Programme of Prime Minister Juha Sipilä's Government, 29 May 2015. Government Publications 12/2015 (http://valtioneuvosto.fi/en/sipila/governmentprogramme). 
coverage and public scrutiny of national EU policy, and this in turn implies less room for manoeuvre for the cabinet.

The divisions have extended to cover even foreign and security policy. There is now more domestic debate about both the substance of EU external relations and the difficulties in reconciling Finnish interests with EU's common policy line. It seems that it is more legitimate than before to stress national interests and bilateral ties, particularly in relations with Russia. Moreover, the budget cuts of the Sipilä government that hit especially development aid but also crisis management activities have been interpreted as diverting Finland away from a 'Nordic' profile but also harming its international credibility, as signals of diminishing international role would equal lack of responsibility and too strong an emphasis on national interest.

So, what has changed? Has the pragmatic, flexible, adaptive and constructive member state turned into an 'awkward' one? To some extent yes, and not quite unexpectedly so. The political calculation of gains and losses has changed. Lessening political consensus implies more chances for even quick changes in policy. Contestation has led to Finland standing even alone in EU level bargaining and to more polarised domestic debate. Yet, no signs of active obstructionism emerge, just more hesitation. In this, it might actually be the mainstream that changes towards being more awkward, and not Finland: Finland still keeps in the mainstream.

Still, the basic equation remains the same: Finland joined the EU for economic and security reasons, and, if anything, the euro crisis and the Ukrainian war have underlined the importance of the European framework for advancing national interests - but significantly, these national interests are now emphasized more, subject to increased domestic contestation, and defended more vigorously in Brussels. There is no real alternative, for instance no Nordic alternative to the EU. Of course one 
can say that this is more a matter of political rhetoric aimed at domestic audiences: after all, in the end the Finnish governments have, although with some reservations, supported various euro area coordination instruments and bailout packages. There is also no systematic evidence of Finnish governments acting tougher in other policy areas in EU level bargaining. However, change is already evident. In terms of EU level bargaining, flexibility may still prevail in less salient issues, but where national (publicly defined) interests are at stake, Finnish governments are bound to show less willingness for compromises than before. If compromise was a central tenet of anti-awkward policy, then a change can be perceived. In terms of policy, what can be expected from Finland in these circumstances is pragmatic cooperation geared towards economic growth rather than big reforms or supporting further centralization.

Domestically the changes are probably more profound. It is plausible to argue that there is no return to the pre-euro crisis era consensus over Europe. Most political parties, including all three current cabinet parties, and their electorates are divided over both integration and specific EU-related policy issues such as immigration, euro zone coordination instruments or relations with Russia. These issues are likely to feature prominently in both national and EU level debates in the next few years. Experience from other EU member states and the Nordic countries also indicates that contestation over EU is normally a long-term phenomenon. On a deeper level, however, we need to see whether domestic consensus is disappearing or at least weakening. This would be a major change for Finland, perhaps towards more openness, clashes and abrupt changes, something that truly awkward action would be about. But in a society where foreign and EU policies have always been based on single national interests defined by the president or the government, any cracks in consensus are surely not a bad thing. 
To conclude, in terms of understanding awkwardness better, the Finnish case is illustrative in two ways. First, it shows the importance of the link between domestic political consensus and awkwardness. The more consensus there is, the more predictable and easy to deal with the country is. Second, the Finnish case also leads one to ponder on the larger change in Europe: a new European mainstream with new, less integrationist norms and values might be forming. Finland would continue in the mainstream, but in reality follow a new line. In this situation, the perception of Finland as a EU member country would not change dramatically, either.

\section{Bibliography}

Alapuro, Risto (2004): What is Western and What is Eastern in Finland? Thesis Eleven 77:1, 85101.

Arter, David (1987): Politics and Policy-Making in Finland: A Study of a Small Democracy in a West European Outpost. Basingstoke: Palgrave Macmillan.

Arter, David (1995): The EU Referendum in Finland on 16 October 1994: A Vote for the West, not for Maastricht. Journal of Common Market Studies 33:3, 361-387.

Arter, David (2000): Small State Influence Within the EU: The Case of Finland's "Northern Dimension Initiative”. Journal of Common Market Studies 38:5, 677-697.

Arter, David (2006): Democracy in Scandinavia: Consensual, majoritarian or mixed? Manchester: Manchester University Press. 
Arter, David (2009): From a Contingent Party System to Party System Convergence? Mapping Party System Change in Postwar Finland. Scandinavian Political Studies 32:2, 221-239.

Auel, Katrin \& Raunio, Tapio (2014): Debating the State of the Union? Comparing Parliamentary Debates on EU Issues in Finland, France, Germany and the United Kingdom. Journal of Legislative Studies 20:1, 13-28.

Haukkala, Hiski \& Ojanen, Hanna (2011): The Europeanization of Finnish foreign policy: Pendulum swings in slow motion. In Reuben Wong \& Christopher Hill (eds.) National and European Foreign Policies: Towards Europeanization. Abingdon: Routledge, 149-166.

Hyvärinen, Anna \& Raunio, Tapio (2014): Who Decides What EU Issues Ministers Talk About? Explaining Governmental EU Policy Co-Ordination in Finland. Journal of Common Market Studies $52: 5,1019-1034$

Jenssen, Andres Todal, Pesonen, Pertti \& Gilljam, Mikael eds. (1998): To Join or Not to Join: Three Nordic Referendums on Membership in the European Union. Oslo: Scandinavian University Press.

Jokela, Juha (2011): Europeanization and Foreign Policy: State Identity in Finland and Britain. Abingdon: Routledge.

Karvonen, Lauri (2014): Parties, Governments and Voters in Finland: Politics under Fundamental Societal Transformation. Colchester: ECPR Press. 
Karvonen, Lauri, Paloheimo, Heikki \& Raunio, Tapio eds. (2016): The Changing Balance of Political Power in Finland. Stockholm: Santérus Academic Press.

Mattila, Mikko \& Raunio, Tapio (2005): Kuka edustaa EU:n vastustajia? Euroopan parlamentin vaalit 2004. Politiikka 47:1, 28-41.

Mattila, Mikko \& Raunio, Tapio (2012): Drifting further apart: National parties and their electorates on the EU dimension. West European Politics 35:3, 589-606.

Mouritzen, Hans (1993): The Two Musterknaben and the Naughty Boy: Sweden, Finland and Denmark in the Process of European Integration. Cooperation and Conflict 28:4, 373-402.

Ojanen, Hanna (1998): The Plurality of Truth: A Critique of Research on the State and European Integration. Ashgate: Aldershot.

Ojanen, Hanna (1999): How to Customise Your Union: Finland and the "Northern Dimension of the EU”. Northern Dimensions, The Finnish Institute of International Affairs, Yearbook 1999, pp. 13-26.

Ojanen, Hanna (2000): Participation and influence: Finland, Sweden and the post-Amsterdam development of the CFSP. Occasional Paper 11, WEU Institute for Security Studies, Paris, January.

Ojanen, Hanna together with Herolf, Gunilla \& Lindahl, Rutger (2000): Non-alignment and European Security Policy: ambiguity at work. Helsinki: Programme on the Northern Dimension of the CFSP, Finnish Institute of International Affairs and Institut für Europäische Politik. 
Ojanen, Hanna (2004): If in "Europe", then in its "core"? Finland. In Wolfram Kaiser \& Jürgen Elvert (eds.) European Union Enlargement: A Comparative History. Abingdon: Routledge, 150169.

Ojanen, Hanna (2008): Finland and the ESDP: 'obliquely forwards'? In Clive Archer (ed.) New Security Issues in Northern Europe: The Nordic and Baltic States and the ESDP. Abingdon: Routledge, 56-77.

Palosaari, Teemu (2011): The Art of Adaptation: A Study on the Europeanization of Finland's Foreign and Security Policy. Tampere: TAPRI Studies in Peace and Conflict Research No. 96.

Pesonen, Pertti ed. (1994): Suomen EU-kansanäänestys 1994: Raportti äänestäjien kannanotoista. Helsinki: Ulkoasiainministeriö, Eurooppatiedotus.

Pursiainen, Christer \& Saari, Sinikukka (2002) Et tu Brute! Finland's NATO Option and Russia. UPI Report 1. Helsinki: Finnish Institute of International Affairs.

Raunio, Tapio (2005): Hesitant Voters, Committed Elite: Explaining the Lack of Eurosceptic Parties in Finland. Journal of European Integration 27:4, 381-395.

Raunio, Tapio (2012a): Semi-presidentialism and European integration: lessons from Finland for constitutional design. Journal of European Public Policy 19:4, 567-584. 
Raunio, Tapio (2012b): 'Whenever the EU is involved, you get problems': Explaining the European policy of The (True) Finns. Sussex European Institute Working Paper 127.

Raunio, Tapio (2015): Finland: An End to Domestic Consensus. In Eleanor E. Zeff \& Ellen B. Pirro (eds.) The European Union and the Member States. $3^{\text {rd }}$ edition, Boulder: Lynne Rienner, 243257.

Raunio, Tapio (2016a): Refusing to be Sidelined: The Engagement of the Finnish Eduskunta in Foreign Affairs. Scandinavian Political Studies 39:4, 312-332.

Raunio, Tapio (2016b): The politicization of EU affairs in the Finnish Eduskunta: Conflicting logics of appropriateness, party strategy or sheer frustration? Comparative European Politics 14:2, 232-252.

Raunio, Tapio \& Tiilikainen, Teija (2003): Finland in the European Union. London: Frank Cass.

Ruostetsaari, Ilkka (2015): Elite Recruitment and Coherence of the Inner Core of Power in Finland: Changing Patterns during the Economic Crises of 1991-2011. Lanham, MD: Lexington Books.

Tiilikainen, Teija (1998): Europe and Finland: Defining the Political Identity of Finland in Western Europe. Aldershot: Ashgate.

Tiilikainen, Teija (2006): Finland - An EU Member with a Small State Identity. Journal of European Integration 28:1, 73-87. 
Väyrynen, Raimo (1993): Finland and the European Community: Changing Elite Bargains. Cooperation and Conflict 28:1, 31-46. 